\title{
Genetic and phenotypic analysis of Vibrio cholerae non-01, non-O139 isolated from German and Austrian patients
}

\author{
F. Schirmeister • R. Dieckmann • S. Bechlars • N. Bier • \\ S. M. Faruque $\cdot$ E. Strauch
}

Received: 28 August 2013 / Accepted: 22 October 2013 /Published online: 10 November 2013

(C) The Author(s) 2013. This article is published with open access at Springerlink.com

\begin{abstract}
Vibrio cholerae belonging to the non-O1, nonO139 serogroups are present in the coastal waters of Germany and in some German and Austrian lakes. These bacteria can cause gastroenteritis and extraintestinal infections, and are transmitted through contaminated food and water. However, non-O1, non-O139 V. cholerae infections are rare in Germany. We studied 18 strains from German and Austrian patients with diarrhea or local infections for their virulence-associated genotype and phenotype to assess their potential for infectivity in anticipation of possible climatic changes that could enhance the transmission of these pathogens. The strains were examined for the presence of genes encoding cholera toxin and toxin-coregulated pilus (TCP), as well as other virulence-associated factors or markers, including hemolysins, repeats-in-toxin (RTX) toxins, Vibrio seventh pandemic islands VSP-1 and VSP-2, and the type III secretion system (TTSS). Phenotypic assays for hemolysin activity, serum resistance, and biofilm formation were also performed. A dendrogram generated by incorporating the results of these analyses revealed genetic differences of the strains correlating with their clinical origin. Non-O1, non-O139 strains from
\end{abstract}

Electronic supplementary material The online version of this article (doi:10.1007/s10096-013-2011-9) contains supplementary material, which is available to authorized users.

F. Schirmeister $\cdot$ R. Dieckmann $\cdot$ S. Bechlars $\cdot$ N. Bier $\cdot$

E. Strauch $(\bowtie)$

Department of Biological Safety, National Reference Laboratory for Monitoring Bacteriological Contamination of Bivalve Molluscs,

Federal Institute for Risk Assessment, Bundesinstitut für

Risikobewertung (BfR), Diedersdorfer Weg 1,

12277 Berlin, Germany

e-mail: Eckhard.Strauch@bfr.bund.de

S. M. Faruque

Centre for Food and Water Borne Diseases, International Centre for

Diarrhoeal Disease Research, Bangladesh, Dhaka, Bangladesh diarrheal patients possessed the TTSS and/or the multifunctional autoprocessing repeats-in-toxin (MARTX) toxin, which were not found in the strains from ear or wound infections. Routine matrix-assisted laser desorption/ionization (MALDITOF) mass spectrometry (MS) analysis of all strains provided reliable identification of the species but failed to differentiate between strains or clusters. The results of this study indicate the need for continued surveillance of $V$. cholerae non-O1, non-O139 in Germany, in view of the predicted increase in the prevalence of Vibrio spp. due to the rise in surface water temperatures.

\section{Introduction}

The Gram-negative bacterium Vibrio cholerae, as a species, is part of the normal flora of the aquatic ecosystems worldwide, but many strains of the species can cause severe disease in humans. Strains of $V$. cholerae belonging to the serogroups $\mathrm{O} 1$ and $\mathrm{O} 139$ are the causative agent of cholera, an epidemic diarrheal disease, which still affects millions of people in most developing countries of Asia, Africa, and Latin America [1]. In Europe, cholera infections are found only rarely, and these patients have a history of traveling from countries where the disease is endemic. In Germany, a total of 17 travel-associated cases were notified and confirmed since 2001 (Robert Koch Institute, http://www3.rki.de/SurvStat/).

However, besides the toxigenic O1 and O139 serogroups, $V$. cholerae strains belonging to more than 200 serogroups are widespread in aquatic environments [2,3]. A number of reports have demonstrated that some strains of these serogroups can cause diarrheal diseases or local infections, but do not have the ability to cause epidemic outbreaks $[3,4]$. Whereas the major virulence factors of toxigenic $V$. cholerae $\mathrm{O} 1$ and $\mathrm{O} 139$ are known to be the cholera toxin (CT) and the toxin-coregulated pilus (TCP), a number of accessory 
virulence factors have been identified which play a synergistic role in the infection process $[5,6]$. These factors include the mannose-sensitive hemagglutinin pilus (MSHA) [7], the repeats-in-toxin (RTX) toxin cluster [8, 9], outer membrane proteins $(\mathrm{OmpU})[10,11]$, and hemolysins $[2,5,7]$. Genes for some of these accessory virulence factors are present in nonO1, non-O139 strains as well and are assumed to play a role in their survival in the natural environment [7].

In central Europe, $V$. cholerae belonging to the non-O1, non-O139 serogroups occur in the coastal waters of the North Sea and Baltic Sea [12, 13], but have also been found in some alkaline lakes [14, 15]. Global warming and climate change is expected to increase the water surface temperatures of seas and lakes of central Europe and has stimulated forecasts that non-cholera Vibrio infections will increase, especially in hot summer periods [16]. Epidemiological information on Vibrio diseases are, up to now, limited, as no systematic monitoring programs for Vibrio species and no surveillance of Vibrio infections in clinical settings have been undertaken.

So far, only sporadic cases with $V$. cholerae non-O1, non-O139 infections have been reported in Germany and Austria [15, 17, 18]. These included a few cases of diarrhea in travelers returning from foreign countries and had been suspected to be cholera, and some cases of local infections, including otitis or wound infection. The latter cases were caused by contact with contaminated seawater after recreational activities like bathing. $V$. cholerae isolates from these cases probably belong to the autochthonous flora of the water.

The aim of this study was to elucidate the phenotypic and genotypic characteristics of clinical isolates from German and Austrian patients with a special focus on strains originating from sea and lake waters. To characterize the pathogenic potential of $V$. cholerae non-O1, non-O139 strains, a number of virulence genes were investigated, including those encoding CT and TCP normally carried by $\mathrm{O} 1$ and $\mathrm{O} 139$ strains, but also occasionally found in non-O1, non-O139 strains. In addition, pathogenicity-related phenotypic traits including hemolytic activity, serum resistance, and biofilm formation were assessed. Strains were further characterized using $r р о B$ sequencing and whole-cell matrix-assisted laser desorption/ionization time-of-flight (MALDI-TOF) mass spectrometry (MS) analysis, and the discriminative potential of these techniques at the strains level was evaluated.

\section{Materials and methods}

Bacterial strains

A total of $18 \mathrm{~V}$. cholerae non-O1, non-O139 isolates from German and Austrian patients and five V. cholerae $\mathrm{O} 1$ or O139 control strains were used in this study (Table 1).
Recent strains were obtained from the Robert Koch Institute, Berlin, or were collected by the Landesamt für Gesundheit und Soziales (LAGuS), Rostock, Germany, and Österreichische Agentur für Gesundheit und Ernährungssicherheit (AGES), Vienna, Austria. Two strains (VN-0168, VN-0169) were isolated from a patient with $V$. vulnificus coinfection. $V$. cholerae $\mathrm{O} 1$ and $\mathrm{O} 139$ reference strains were used as controls to validate the tests. One strain, VN-0309 (veterinary isolate from a doctor fish, Garra rufa), showed a strong and robust biofilm formation, and was used in the biofilm assay as a reference strain.

Species identities of all strains were confirmed by standard biochemical assays, species-specific polymerase chain reaction (PCR) targeting the toxR gene [19], sequencing of a fragment of the rpoB gene [20], and MALDI-TOF MS analysis.

\section{Strain cultivation}

Strains were routinely cultivated in Luria-Bertani (LB) medium (Merck, Darmstadt, Germany) at $37^{\circ} \mathrm{C}$. Mannose fermentation was carried out by pregrowing strains on LB agar for $24 \mathrm{~h}$ at $37^{\circ} \mathrm{C}$. Five milliliters of mannose fermentation broth (1\% mannose, $0.0075 \%$ bromothymol blue, $1 \%$ peptone, $0.5 \% \mathrm{NaCl}, \mathrm{pH} 7.4$ ) were inoculated using an inoculating needle, incubated at $37^{\circ} \mathrm{C}$, and examined for mannose fermentation at $24 \mathrm{~h}$ and after 5 days. Sucrose fermentation was investigated in the same medium by replacing mannose with sucrose. The blood agar base (Mast Diagnostics, Rheinfeld, Germany) used for the qualitative hemolysis test contained $5 \%$ defibrinated sheep blood.

\section{MALDI-TOF MS analysis}

Bacteria were cultivated on LB agar plates overnight at $37^{\circ} \mathrm{C}$. Two different sample preparation procedures were employed. For direct transfer, a single colony of fresh overnight cultures was transferred onto a stainless steel target using a sterile toothpick and overlaid with matrix solution containing $10 \mathrm{mg} / \mathrm{ml} \alpha$-cyano-4-hydroxycinnamic acid in acetonitrile, water, and trifluoroacetic acid (50:47.5:2.5, v/v). In the second procedure, bacterial proteins were extracted from cells using ethanol and formic acid according to the manufacturer's protocol (Bruker Daltonik, Bremen, Germany). All samples were spotted in triplicate.

MALDI-TOF MS analysis was performed using a Microflex LT system (Bruker Daltonik) mass spectrometer following the manufacturer's settings. Captured spectra were analyzed using automated control and the Bruker Biotyper 3.0 software and library. Bacterial test standard (BTS; part no. 255343, Bruker Daltonik) was used for calibration and validation. Criteria used for analysis were as recommended by the manufacturer for species identification. 
Table 1 List of non-O1, nonO139 Vibrio cholerae strains and control O1 or O139 strains used in this study

\begin{tabular}{|c|c|c|c|c|}
\hline Strain & Year of isolation & Type of infection & Origin & Source \\
\hline VN-0168 & 2010 & wound infection* & Germany & LAGuS \\
\hline VN-0169 & 2010 & wound infection* & Germany & LAGuS \\
\hline $\mathrm{VN}-0210$ & 2011 & diarrhea/travel disease & Tunisia & RKI \\
\hline $\mathrm{VN}-0211$ & 2011 & diarrhea/travel disease & Italy & RKI \\
\hline VN-0297 & 1995 & otitis & Germany & $\mathrm{BfR}$ \\
\hline $\mathrm{VN}-0298$ & 1995 & otitis & Germany & $\mathrm{BfR}$ \\
\hline VN-0299 & 1996 & diarrhea/travel disease & Tunisia & $\mathrm{BfR}$ \\
\hline $\mathrm{VN}-0300$ & 1999 & diarrhea, peritonitis & unknown & $\mathrm{BfR}$ \\
\hline VN-0301 & 2000 & otitis & Austria & $\mathrm{BfR}$ \\
\hline VN-0302 & 2012 & diarrhea & Germany & RKI \\
\hline VN-0303 & 2012 & otitis & Hungary & RKI \\
\hline VN-0304 & 2012 & diarrhea/travel disease & Egypt & RKI \\
\hline VN-0305 & 2012 & otitis & Germany & RKI \\
\hline VN-0307 & 2012 & otitis & Germany & RKI \\
\hline VN-0308 & 2012 & diarrhea/travel disease & Romania & RKI \\
\hline $\mathrm{VN}-0313$ & 2000 & otitis & Austria & AGES \\
\hline VN-0314 & 2005 & otitis & Austria & AGES \\
\hline VN-0315 & 2011 & diarrhea/travel disease & Cuba & AGES \\
\hline \multicolumn{5}{|l|}{ Control strains } \\
\hline NIH35A3 (O1) & 1941 & diarrhea & India & $\mathrm{BfR}$ \\
\hline NIH41 (O1) & 1941 & diarrhea & India & $\mathrm{BfR}$ \\
\hline $1576(\mathrm{O} 1)$ & 1959 & diarrhea & Thailand & BfR, [42] \\
\hline $1360(\mathrm{O} 1)$ & 1959 & diarrhea & Thailand & BfR, [42] \\
\hline MO45 (O139) & 1992 & diarrhea & India & $\mathrm{BfR}$ \\
\hline
\end{tabular}

\section{PCR genotyping}

Genomic DNA was extracted using the RTP Bacteria DNA Kit from STRATEC Molecular, Berlin, Germany. PCR reactions were performed using a Mastercycler EP Gradient (Eppendorf, Hamburg, Germany) in a volume of $25 \mu \mathrm{l}$ with $1 \times$ PCR buffer $\left(2 \mathrm{mM} \mathrm{MgCl}_{2}\right), 0.2 \mathrm{mM}$ of each dNTP, $0.2 \mu \mathrm{M}$ of each primer, and $1.5 \mathrm{U}$ of Dream Taq DNA Polymerase (Fermentas, St. Leon-Rot, Germany). The PCR primers, target genes, and amplicon sizes are shown in Table 2.

PCR-based amplification of the rроB gene and analysis of the products were conducted as described previously [21]. Sequences of $871 \mathrm{bp}$ encoding a part of the $r р о B$ gene [20] of all strains were aligned using the Accelrys Gene version 2.5 software (Accelrys Ltd., Cambridge, UK) and a dendrogram was calculated using the unweighted pair group method analysis (UPGMA) algorithm with absolute differences. Sequencing reactions were performed commercially at Eurofins MWG Operon, Ebersberg, Germany. Primers were synthesized by Metabion International AG, Planegg/ Martinsried, Germany.
Hemolytic activity of bacterial cells and culture supernatants on human erythrocytes

Quantitative hemolysis assay was carried out as described by Bier et al. [22], and each strain was tested three times. Hemolytic activities of cells and supernatant were tested separately, and an observed hemolysis of below $20 \%$ was rated as negative.

\section{Serum resistance}

The serum resistance test was carried out as described previously $[22,23]$. Isolates that showed growth in the presence of 60-80\% human serum were classified as serum resistant. Isolates that grew in the presence of $20-40 \%$ and $0-10 \%$ human serum were classified as intermediate and sensitive, respectively. For Fig. 2 (binary data), only strains that grew in 60-80\% serum were rated resistant.

Biofilm formation

The ability of the bacteria to form a biofilm was assessed according to Mahoney et al. [24], with minor modifications. 
Table 2 Polymerase chain reaction (PCR) primers, targets, and amplicon sizes used for genotyping

\begin{tabular}{|c|c|c|c|c|}
\hline Target gene & Primer & Sequence & Amplicon size (bp) & References \\
\hline$r f b \mathrm{O} 139$ cluster & $\mathrm{O} 139 \mathrm{~F}$ & AGCCTCTTTATTACGGGTGG & & {$[43,44]$} \\
\hline$r f b$ O139 cluster & O139R & GTCAAACCCGATCGTAAAGG & 449 & {$[43,44]$} \\
\hline$r f b$ O1 cluster & $\mathrm{O} 1 \mathrm{~F}$ & GTTTCACTGAACAGATGGG & & {$[43,44]$} \\
\hline$r f b$ O1 cluster & O1R & GGTCATCTGTAAGTACAAC & 192 & {$[43,44]$} \\
\hline$c t x$ & $\operatorname{ctxA} 1$ & CTCAGACGGGATTTGTTAGGCACG & & {$[2]$} \\
\hline$c t x$ & $\operatorname{ctxA} 2$ & TCTATCTCTGTAGCCCCTATTACG & 301 & {$[2]$} \\
\hline $\operatorname{tox} R$ & UtoxF & GASTTTGTTTGGCGYGARCAAGGTT & & {$[19]$} \\
\hline $\operatorname{tox} R$ & VctoxR & GGTTAGCAACGATGCGTAAG & 640 & {$[19]$} \\
\hline rроB & CM32b-F & CGGAACGGCCTGACGTTGCAT & & {$[20]$} \\
\hline rроB & $1110 \mathrm{~F}-\mathrm{R}$ & GTAGAAATCTACCGCATGATG & 984 & {$[20]$} \\
\hline гроB & $1661 \mathrm{~F}^{*}$ & TTYATGGAYCARAACAACCC & - & {$[20]$} \\
\hline rроB & $1783 b^{*}$ & GGACCTTYAGGNGTTTCGAT & - & {$[20]$} \\
\hline hlyA class/ET & hlyA-489F & GGCAAACAGCGAAACAAATACC & $727 / 738$ & {$[5,6]$} \\
\hline hlyA ET & hlyA-744F & GAGCCGGCATTCATCTGAAT & 481 & {$[5,6]$} \\
\hline hlyA class/ET & hlyA-1184R & CTCAGCGGGCTAATACGGTTTA & & {$[5,6]$} \\
\hline $\operatorname{tcp} A$ & tcpA-F_Class-ET & CACGATAAGAAAACCGGTCAAGAG & & {$[5,6]$} \\
\hline tcpA class & tcpA-R_class & TTACCAAATGCAACGCCGAATG & 620 & {$[5,6]$} \\
\hline tcpA ET & tcpA-R_ET & AATCATGAGTTCAGCTTCCCGC & 453 & {$[5,6]$} \\
\hline TTSS $v c s C 2$ & TTSS_vcsC2-A & CGTTACCGATGCTATGGGT & & {$[2]$} \\
\hline TTSS $v c s C 2$ & TTSS_vcsC2-B & AGAAGTCGGTTGTTTCGGTAA & 535 & {$[2]$} \\
\hline TTSS $v \operatorname{cs} N 2$ & TTSS_vesN2-A & CAGTTGAGCCAATTCCATT & & {$[2]$} \\
\hline TTSS $v \operatorname{cs} N 2$ & TTSS_vcsN2-B & GACCAAACGAGATAATG & 484 & {$[2]$} \\
\hline TTSS $v s p D$ & TTSS_vspD-A & AACTCGAAGAGCAGAAAAAAGC & & {$[2,31]$} \\
\hline TTSS $v s p D$ & TTSS_vspD-B & CTTCCCGCTTTTGATGAAATG & 422 & {$[2,31]$} \\
\hline TTSS vcs $V 2$ & TTSS_vesV2-A & TTTGGCTCACTTGATGGG & & {$[2,31]$} \\
\hline TTSS vcs $V 2$ & TTSS_vcsV2-B & GCCACATCATTGCTTGCT & 742 & {$[2,31]$} \\
\hline$m s h A$ & VC0409-F & ATTCTCGGTATCTTGGCCGTC & & {$[7]$} \\
\hline$m \operatorname{sh} A$ & VC0409-R & ACAAGCAGTTCCAGCAACCC & 459 & {$[7]$} \\
\hline rstR class & VC-rstR-class-F & CTCATCAGCAAAGCCTCCATC & & [7] \\
\hline rstR class & VC-rstR-class-R & TAGCAAATGGTATCGGCGTTG & 241 & {$[7]$} \\
\hline$r s t R E T$ & VC1455-F & AGCCAACCAAAGAAAGGCAAT & & {$[7]$} \\
\hline$r s t R E T$ & VC1455-R & TCATCTGTGGCCCATCTTCC & 186 & {$[7]$} \\
\hline rstR Calc & VC-rstR-calc-F & CCAGCATTTCTGTTTCTTTG & & {$[7]$} \\
\hline rstR Calc & VC-rstR-calc-R & GGCAACAAAGCACATTAAAG & 104 & {$[7]$} \\
\hline$d t h$ & VCA1111-F & CAACCATGCACTAAATTGCCC & & This study \\
\hline$d t h$ & VCA1111-R & TGGAAGTCATTACACCCACGC & 526 & This study \\
\hline $\operatorname{ch} x A$ & VC-chxA-F & TGTGTGATGATGCTTCTGG & & {$[33]$} \\
\hline $\operatorname{ch} x A$ & VC-chxA-R & TTATTTCAGTTCATCTTTTCGC & 2000 & {$[33]$} \\
\hline$r t x A$ & VC1451-F & GATTCTTCCGTTCAAGCTCCG & & This study \\
\hline$r t x A$ & VC1451-R & TGGTTCAGGCTGTTGCACAC & 2571 & This study \\
\hline$r t x C$ & VC1450-F & TGCAAATCTCACATTAGCGCA & & This study \\
\hline$r t x C$ & VC1450-R & CCACTGCACCTTTCGGATACA & 430 & This study \\
\hline ompU & ompU-F & ACGCTGACGGAATCAACCAAAG & & {$[2]$} \\
\hline ompU & ompU-R & GCGGAAGTTTGGCTTGAAGTAG & 869 & {$[2]$} \\
\hline$z o t$ & zot-F & TCGCTTAACGATGGCGCGTTTT & & {$[2]$} \\
\hline$z o t$ & zot-R & AACCCCGTTTCACTTCTACCCA & 947 & {$[2]$} \\
\hline ace & ace-F & TAAGGATGTGCTTATGATGGACACCC & & {$[2]$} \\
\hline ace & ace-R & CGTGATGAATAAAGATACTCATAGG & 289 & {$[2]$} \\
\hline VSP-1 & Vch-VspI-fo & GCTCTCGCCAGCAAGGAGCTG & & {$[7]$} \\
\hline
\end{tabular}


Table 2 (continued)

\begin{tabular}{lllll}
\hline Target gene & Primer & Sequence & Amplicon size (bp) & References \\
\hline VSP-1 & Vch-VspI-re & CCGTCGAAGTGAACGGCGAAC & 1700 & {$[7]$} \\
VSP-2 & Vch-VspII-fo & TGCCCATTCCGCTAAGTGTTC & 800 & {$[7]$} \\
VSP-2 & Vch-VspII-re & GCAAAAGCACTGCGTAAACTG & {$[7]$} \\
\hline
\end{tabular}

*Sequencing primers

LB overnight cultures were inoculated at tenfold or hundredfold dilutions into $225 \mu \mathrm{l}$ of Heart Infusion Broth (HIB) per well of a polystyrene microtiter plate and grown for $4 \mathrm{~h}$ at $37^{\circ} \mathrm{C}$ with shaking at $200 \mathrm{rpm}$. Each strain was tested four times for each dilution in an experiment. The $\mathrm{OD}_{590}$ was measured for the determination of growth. The cultures were then expelled from the plates, which were washed twice with $250 \mu \mathrm{l}$ of distilled water per well. Plates were dried overnight and the biofilm was fixed at $60{ }^{\circ} \mathrm{C}$ for $60 \mathrm{~min}$. Following staining with $250 \mu \mathrm{l}$ of $0.1 \%$ crystal violet (w/v in distilled water) solution for $20 \mathrm{~min}$, the dye solution was removed, the wells were washed three times with distilled water, and dried for $2 \mathrm{~h}$. The dye was redissolved in $300 \mu \mathrm{l}$ of $33 \%$ acetic acid for $20 \mathrm{~min}$, then $50 \mu \mathrm{l}$ were removed and diluted twofold in $33 \%$ acetic acid.

The $\mathrm{OD}_{570}$ was measured, and the biofilm quantified as absorbance normalized to the cell density of the initial culture $\left(\mathrm{OD}_{590}\right)$. Biofilm formation was investigated using V. cholerae $\mathrm{VN}-0309$ as a reference, which showed a robust biofilm formation phenotype under the test conditions. Biofilm formation of this strain determined photometrically at $570 \mathrm{~nm}$ after reextraction of crystal violet from fixed cells was set to $100 \%$. The biofilm formation was defined as none $(0-10 \%$ of biofilm activity of $\mathrm{VN}-0309)$, weak (11-40\%), intermediate $(41-70 \%)$, and strong $(>70 \%)$. Strains that showed strong or intermediate biofilm formation were rated as positive for Fig. 2 (binary data).

\section{Results}

Species determination

All strains had been routinely typed in the reference laboratory as $V$. cholerae using standard biochemical tests [25]. A multiplex PCR targeting toxR, $c t x A$, and the $r f b$ sequences specific for $\mathrm{O} 1$ and $\mathrm{O} 139$ serogroups $[19,26]$ was used for further subtyping of all $V$. cholerae isolates. While all strains were positive in the toxR PCR specific for $V$. cholerae, only the control strains were positive for $c t x A$. As expected, four of the toxigenic strains were positive in the $\mathrm{O} 1$ serogroup PCR and one toxigenic strain was positive in the $\mathrm{O} 139$ serogroup PCR, thus confirming the validity of the PCR tests. Further species confirmation was obtained by partial rpoB sequencing and MALDI-TOF MS analysis.

$r p o B$ sequencing

The nucleotide sequences of an $871 \mathrm{bp}$ fragment of the rроB gene which has been evaluated for species identification of Vibrio species $[20,21]$ were determined for all 23 isolates and used for the construction of a dendrogram [20]. Figure 1 shows the hierarchical clustering on the basis of sequence differences. The sequences of all toxigenic strains and three non-O1, non-O139 strains were identical, the other strains showed few nucleotide exchanges, with an overall similarity of $99.4 \%$. Two strains (VN-0303, VN-0304) showed slightly greater differences of up to $3.4 \%$ compared to the sequences derived from the other strains in the stretch of $871 \mathrm{bp}$ and

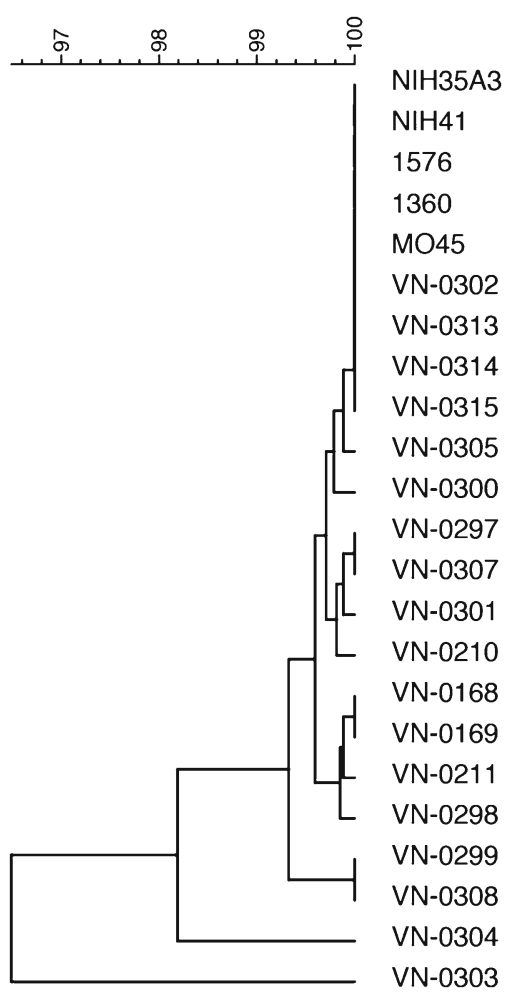

Fig. 1 Tree based on partial rpoB sequences created by the unweighted pair group method analysis (UPGMA) with absolute differences. Similarity is shown in percent 
between each other. Nevertheless, alignment to databases using BlastN (http://blast.ncbi.nlm.nih.gov/Blast.cgi) clearly confirmed the classification of the species as $V$. cholerae. Despite the sequence variations, nearly all nucleotide exchanges were synonymous. The deduced protein sequences were identical in 20 strains, two strains possessed one amino acid (aa) difference in the stretch of 290 aa (VN0211, VN-0303), and one strain (VN-0304) had three different aa in the protein sequence.

\section{Bacterial identification using MALDI-TOF MS}

MALDI-TOF MS using intact cells successfully identified all $V$. cholerae isolates under study to the species level with high confidence. The observed set of high-intensity speciesidentifying biomarker ions were tentatively assigned and included ribosomal proteins such as $50 \mathrm{~S}$ ribosomal protein $\mathrm{L} 36$ $(\mathrm{m} / \mathrm{z} 5,125), 50 \mathrm{~S}$ ribosomal protein L32 (m/z 6,168), ribosomal protein $\mathrm{L} 30(\mathrm{~m} / \mathrm{z} 6,455), 30 \mathrm{~S}$ ribosomal protein $\mathrm{S} 16(\mathrm{~m} / \mathrm{z}$ 9,084), DNA-binding protein HU- $\alpha(\mathrm{m} / \mathrm{z} 9,493)$ and $-\beta(\mathrm{m} / \mathrm{z}$ $9,368)$, and integration host factor subunit $\alpha(\mathrm{m} / \mathrm{z} 10,991)$ and $\beta(\mathrm{m} / \mathrm{z}$ 10,548). To determine if the method could be used for further differentiation of O1, O139 serogroups from non-O1, non-O139 serogroups, all spectra from both groups that were obtained using the direct transfer method and after the extraction of proteins from bacterial cells were compared. First, a dendrogram was created using the Biotyper software; however, there was no overall clustering of serotypes observed in this dendrogram with either sample preparation method (data not shown). In addition, the panel of spectra was screened for biomarkers that could distinguish serogroups by visual inspection using flexAnalysis software (Bruker Daltonik). Again, no reproducible biomarker ions with specificities on the serotype level were detectable. In addition, the influence of increasing the number of shots used for summed spectra from 240 shots to 2,000 shots was investigated, but without further success.

\section{Genotyping by PCR}

The presence of a number of genes usually associated with toxigenic V. cholerae strains were investigated in the non-O1, non-O139 strains (Table 3). None of the non-O1, non-O139 strains contained the cholera toxin gene $(\operatorname{ctx} A)$ and genes of the CTX element (zot, ace). The rstR gene, which shows significant sequence variations and is part of the CTX filamentous phage $[27,28]$, was not present in the non-O1, nonO139 strains. Primer combinations for three $r s t R$ alleles (Classical, El-Tor, Calcutta) were tested. tcpA was tested for two alleles (Classical, El-Tor), and all non-O1, non-O139 strains were found to be negative.

$V$. cholerae strains of the seventh pandemic possess two genomic islands, VSP-1 and VSP-2, which are absent from strains of the sixth pandemic and most environmental isolates
[7]. The $\mathrm{O} 1$ classical strains used in this study were isolated during the sixth pandemic and gave the expected PCR products, with the VSP-1 and VSP-2 primers revealing the absence of the two islands. Most of the non-O1, non-O139 strains also did not possess the two islands ( 12 out of 18 , Table 3 ). In the remaining six strains, only one PCR assay, either the PCR assay for VSP-1 or VSP-2, gave the expected PCR products. In three of these strains (VN-0168, VN-0169, VN-0300), amplification with the VSP-1 primer yielded a PCR product of $3 \mathrm{kbp}$ instead of $1.7 \mathrm{kbp}$. However, partial sequencing of the PCR amplicon confirmed that most of the VSP-1 island was absent. In three other strains, no PCR product was visible either for VSP-1 (one strain) or VSP-2 (two strains). We did not undertake any efforts to find out if parts of the pandemic islands were present in these strains. Other reports indicate that the pandemic islands are rarely found in non-O1, nonO139 strains and carry only some of the open reading frames of these islands if present $[2,7]$.

We studied all non-O1, non-O139 strains for putative accessory virulence-associated factors like the MSHA [7], the RTX toxin cluster $[8,9]$, outer membrane proteins (OmpU) $[10,11]$, and hemolysins $[2,5,7]$. All strains were negative for the PCR assay targeting the MSHA pilus, while all toxigenic strains were positive, as expected (Table 3 ). MSHA is a type 4 pilus involved in host colonization and acts as a receptor of phages [29]. Two RTX toxin-specific PCR assays were performed. One PCR which targets the $r t x A$ gene encoding the multifunctional autoprocessing repeats-in-toxin (MARTX) toxin was positive for five strains out of the 18 non-O1, nonO139 strains. In contrast, the $r t x C$ PCR targeting an acyltransferase gene of the $r t x$ gene cluster was positive in all 18 strains. The toxigenic O139 strain was positive for both PCR assays, whereas all classical O1 strains were negative for the two PCRs, as $\mathrm{O} 1$ classical strains have a deletion in the RTX gene cluster [25]. The gene of the outer membrane protein OmpU was found in nine non-O1, non-O139 strains and in all toxigenic control strains.

The hemolysin gene hlyA was tested according to Rivera et al. [5]. All non-O1, non-O139 strains were positive for the classical/El-Tor hlyA PCR. One strain (VN-0303) showed only one PCR fragment and was tentatively classified as negative. The same strain did not harbor the $d t h$ gene encoding the $\delta$-thermostable hemolysin [30], which was found in 21 out of all $23 \mathrm{~V}$. cholerae strains used in this study.

Some virulence factors have been identified in non-O1, non-O139 strains that do not seem to be present in toxigenic strains. A type III secretion system (TTSS) system was described that shares homology to a $V$. parahaemolyticus TTSS gene cluster [2,31]. Using a set of four primer pairs targeting different genes of this secretion system [2,31], we identified six strains that harbor the system, while the remaining 12 nonO1, non-O139 strains and the toxigenic strains were negative. Recently, the discovery of cholix toxin was reported in 


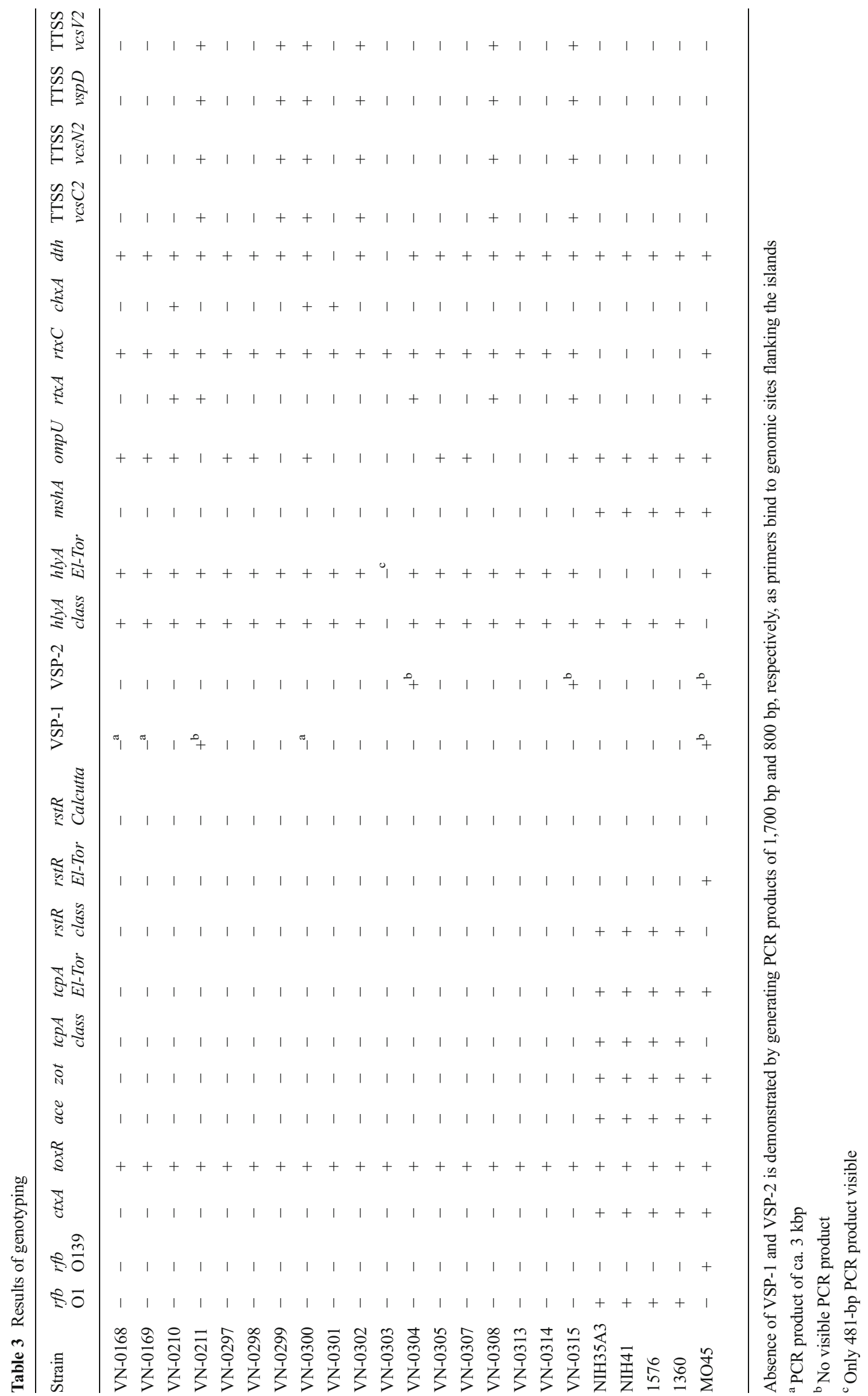


$V$. cholerae strains [32], which could not be found in O1, O139 strains according to Awasthi et al. [33]. Using the PCR assay described in the latter publication, we could identify the chxA gene in three non-O1, non-O139 strains.

\section{Phenotypical assays}

Some biochemical properties can be variable between strains of the same species. Very rarely, $V$. cholerae strains are found that are sucrose negative, while the ability to utilize mannose is much more variable [25]. All strains of this study were sucrose positive, while mannose fermentation was variable in the group of non-O1, non-O139 strains. Five of eighteen non-O1, non-O139 strains and all five toxigenic strains were able to ferment mannose (Table 4).

Biofilm formation was investigated at $37{ }^{\circ} \mathrm{C}$ using V. cholerae $\mathrm{VN}-0309$ as the reference, which showed a robust biofilm formation under the test conditions. The biofilm formation activities of all strains were rated against this reference strain. Only one strain (VN-0301) showed strong biofilm activity and six strains, including one O1 strain (NIH41), showed intermediate activity (Supplemental Fig. S1).

The hemolytic properties of all strains were tested qualitatively on agar plates and quantitatively in a photometric assay. On sheep blood agar, the four classical O1 strains and only one nonO1, non-O139 (VN-0301) strain were not hemolytic, while all other strains were hemolysis positive. Additionally, we studied hemolysis of human erythrocytes in a quantitative approach using logarithmic growing cells and their culture supernatants separately (Supplemental Fig. S2). In this approach, the direct contact of bacterial cells with the erythrocytes led to a complete lysis of the cells within $2 \mathrm{~h}$ for most of the non-O1, non-O139 strains; the hemolytic activity of one toxigenic $\mathrm{O} 1$ strain (NIH35A3) was low (below $20 \%$ ) and was scored as nonhemolytic. The remaining four toxigenic strains and two nonO1, non-O139 strains (VN-0211, VN-0313) were judged as positive, since they displayed hemolytic activity between 30 to $60 \%$. Culture supernatants of four non-O1, non-O139 strains (VN-0298, VN-0303, VN-0304, VN-0307) were scored as negative (hemolysis below $20 \%$ ), whereas that of the other strains were positive for hemolysis.

Resistance to human serum was tested by growing cells in a medium containing different concentrations of serum. Four strains, including one $\mathrm{O} 1$ strain, were resistant to serum, five strains showed intermediate resistance, and the remaining strains were sensitive (Supplemental Table S1).

All phenotyping and genotyping results were merged in a binary figure (Fig. 2), in which the clinical origin of the strains
Table 4 Phenotypic characteristics of Vibrio cholerae strains

\begin{tabular}{|c|c|c|c|c|c|c|c|}
\hline Strain & Sucrose & Mannose & $\begin{array}{l}\text { Serum } \\
\text { resistance }\end{array}$ & $\begin{array}{l}\text { Biofilm } \\
\text { formation }\end{array}$ & $\begin{array}{l}\text { Sheep } \\
\text { blood } \\
\text { agar }\end{array}$ & $\begin{array}{l}\text { Hemolysis } \\
\text { (cells) }\end{array}$ & $\begin{array}{l}\text { Hemolysis } \\
\text { (supernatant) }\end{array}$ \\
\hline VN-0168 & + & - & sensitive & intermediate & + & + & + \\
\hline VN-0169 & + & - & sensitive & intermediate & + & + & + \\
\hline VN-0210 & + & + & sensitive & intermediate & + & + & + \\
\hline VN-0211 & + & - & resistant & weak & + & + & + \\
\hline VN-0297 & + & - & intermediate & none & + & + & + \\
\hline VN-0298 & + & - & sensitive & weak & + & + & - \\
\hline VN-0299 & + & - & intermediate & weak & + & + & + \\
\hline VN-0300 & + & + & sensitive & weak & + & + & + \\
\hline VN-0301 & + & - & intermediate & strong & - & + & + \\
\hline VN-0302 & + & - & sensitive & intermediate & + & + & + \\
\hline VN-0303 & + & - & sensitive & weak & + & + & - \\
\hline VN-0304 & + & - & intermediate & none & + & + & - \\
\hline VN-0305 & + & - & sensitive & intermediate & + & + & + \\
\hline VN-0307 & + & - & sensitive & weak & + & + & - \\
\hline VN-0308 & + & - & resistant & weak & + & + & + \\
\hline VN-0313 & + & + & resistant & weak & + & + & + \\
\hline VN-0314 & + & + & sensitive & weak & + & + & + \\
\hline VN-0315 & + & + & sensitive & weak & + & + & + \\
\hline NIH35A3 & + & + & sensitive & none & - & - & + \\
\hline NIH41 & + & + & resistant & intermediate & - & + & + \\
\hline 1576 & + & + & sensitive & none & - & + & + \\
\hline 1360 & + & + & sensitive & none & - & + & + \\
\hline MO45 & + & + & intermediate & none & + & + & + \\
\hline
\end{tabular}


Fig. 2 Grouping of isolates based on phenotypic and genotypic traits. Similarity patterns were determined by complete linkage using simple matching of binary data (BioNumerics version 6.6.4, Applied Maths, Sint-MartensLatem, Belgium). For the simplification of interpretation, the results of $t c p A$ (two alleles) and $r s t R$ (three alleles) are summarized in one column. $\mathrm{O}=$ diarrheagenic strains, $\Delta=$ strains from local infections

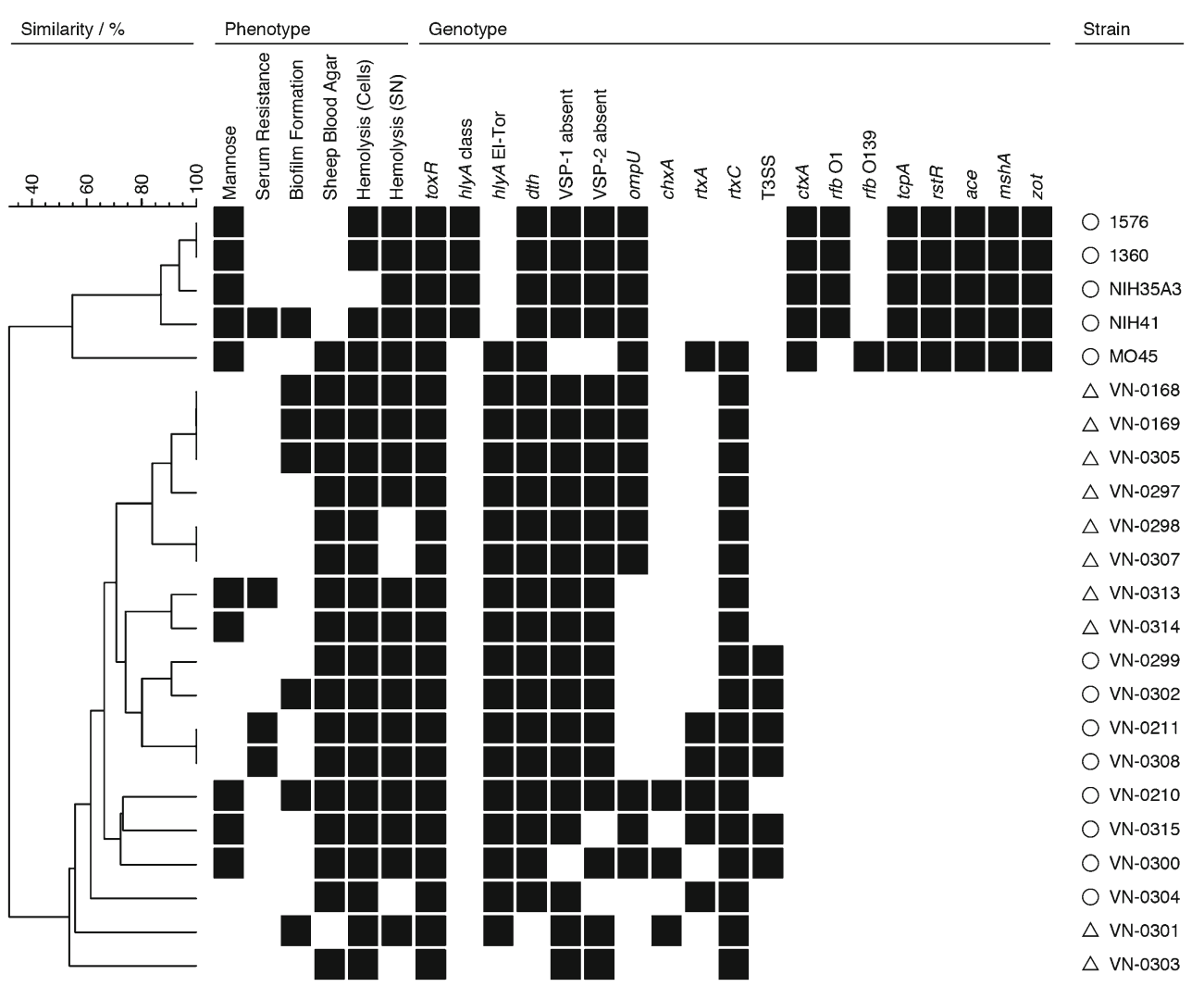

is indicated. Ten non-O1, non-O139 strains were associated with local infections like otitis and wound infection (two strains), and eight strains caused organic infections leading to diarrhea. In the binary table, the O1, O139 control strains are included as well. The cluster analysis of all genotypic and phenotypic results clearly revealed that the toxigenic $\mathrm{O} 1$ and O139 strains form a cluster separated from the non-O1, nonO139 strains. This is due to the fact that all genotypic assays targeting the main cholera virulence factors and accessory virulence factors (ctx, zot, ace, tcp $A, r s t R$, serogroups $\mathrm{O} 1$ and O139) were absent in the non-O1, non-O139 strains in our study. The binary data set, however, revealed an interesting result. When the nature of the clinical infection is indicated, the analysis shows that all diarrheagenic strains possess either the TTSS (three strains) or the MARTX toxin (two strains) or both virulence factors together (three strains), while the ten strains causing localized infections are negative for the respective genes. The TTSS has been shown to induce diarrhea in an animal model [31] and is absent from toxigenic strains. The $r t x A$ gene encoding MARTX is present in toxigenic O1, ElTor biotype, and O139 strains, and can be found in environmental strains with high frequency [8]. The negative results of the rtxA PCR in some non-O1, non-O139 strains means that the $r t x A$ gene is (partially) absent, or that a different $r t x A$ gene variant occurs. The role of the gene product of the $r t x C$ gene which is present in all non-O1, non-O139 strains is, so far, unclear; it may be necessary for posttranslational activation of
MARTX by acetylation [9]. However, $r t x C$-negative mutants seem to produce a functional MARTX protein [34].

All other phenotypic and genotypic traits studied occur with varying frequencies in the two groups.

\section{Discussion}

Vibrio infections are rare in Germany. However, very little epidemiological information is available for these strains, as no monitoring programs or surveillance of Vibrio infections are carried out. In the coastal waters of Germany and in some lakes in Germany and Austria, pathogenic non-O1, non-O139 $V$. cholerae are present and were found to occasionally cause human infections [12, 15]. Climate warming could lead to increased Vibrio concentrations, especially during hot periods in summer months, thus, predictions are that Vibrio infections will increase in the Baltic Sea area [16]. A correlation between increased Vibrio infections and elevated water temperatures in the Baltic has already been observed [18]. In this study, 18 non-O1, non-O139 $V$. cholerae isolates were analyzed for phenotypic and genotypic traits in comparison to five toxigenic $V$. cholerae $\mathrm{O} 1$ or $\mathrm{O} 139$ strains. Some of the non-O1, non-O139 strains are from foreign countries, as they were isolated from returned travelers with diarrheal symptoms which were suspected to be caused by $V$. cholerae infections. Other strains were obtained from patients who contracted 
infections through recreational activities in sea and lake waters.

Species confirmation using rpoB sequencing and MALDITOF MS were undertaken and the methods were evaluated for their discriminative value below the species level. In case of $r p o B$ sequencing, this can clearly be denied, as four rро $B$ sequences of non-O1, non-O139 strains were identical to the sequences of the toxigenic strains, and the remaining strains possessed a varying degree of sequence differences, although the deduced protein sequences were highly similar.

MALDI-TOF MS analyses were undertaken on a mass spectrometer developed for routine diagnostics (Bruker MALDI Biotyper). This methodology was originally developed to provide bacterial identification on the species level $[21,35,36]$. Spectra are typically composed of highly conserved housekeeping proteins like ribosomal proteins. Therefore, it could be expected that this technique has limitations regarding the discrimination of bacteria below the species level. Nevertheless, different studies reported on the usefulness of the method for the differentiation of Salmonella subspecies, a limited number of Salmonella serotypes, Shiga-toxin-producing Escherichia coli serotypes, and E. coli pathotypes [37-39]. However, in this study, MALDITOF MS using the MALDI Biotyper system based on a Microflex LT machine with the evaluation criteria developed for species identification was ineffective for differentiating O1, O139 from non-O1, non-O139 isolates.

The phenotyping and genotyping of putative pathogenicity associated traits were combined in a binary table to characterize the clinical non-O1, non-O139 strains isolated from patients in our region (Fig. 2). The cluster analysis clearly separated the toxigenic strains from the non-O1, non-O139 strains, but also revealed genetic differences of the latter strains correlating with the nature of the clinical infection. The analysis showed that TTSS and $r t x A$ genes were present only in non-O1, non-O139 strains of $V$. cholerae which were from diarrhea cases.

Other virulence factors like the cholix toxin gene $\operatorname{ch} x \mathrm{~A}$ could be detected in strains of both clinical groups, but only with low frequency ( 3 out of 18 strains positive for the $\operatorname{ch} x A$ gene). This toxin seems to be associated with non-O1, nonO139 strains [33], though its occurrence in O1, O139 strains was described [32]. The cholix toxin is an eukaryotic elongation factor-2-specific ADP-ribosyltransferase, whose function in infections is unclear. It was suggested that it may be more associated with extraintestinal infections than enterotoxicity [33]. The ompU gene encoding an outer membrane protein, which contributes to the survival of pathogens in host organisms and is involved in resistance to antimicrobial peptides $[10,11]$, was found in both clinical groups.

Hemolysis zones are often observed on blood agar plates when non-O1, non-O139 strains are investigated [2]. With one exception, all non-O1, non-O139 strains showed hemolytic activity on sheep blood agar, and most of them were hemolytic for human erythrocytes. The genotypic analysis revealed that all strains except for one possessed the El-Tor hemolysin gene $h l y A$, which is frequently observed in non-O1, non-O139 strains $[2,5-7]$. Another hemolysin gene, $d t h$, which encodes the $\delta$-thermostable hemolysin, similar to the $V$. parahaemolyticus hemolysin (Tdh), was present in 16 of the 18 strains. The role of this hemolysin in disease is unclear; in toxigenic $\mathrm{O} 1$ strains, it does not directly contribute to virulence [30]. The phenotypic and genotypic results concerning the hemolytic traits of the non-O1, non-O139 strains do not indicate a difference between the two clinical groups.

Further phenotypic properties like mannose fermentation, serum resistance, or biofilm formation were found in few strains of the two clinical groups; however, the majority of strains was negative. Human serum resistance is a specific characteristic of pathogenic V. vulnificus strains [22, 40]; however, in the non-O1, non-O139 strains, that does not seem to be the case. Biofilm formation has been studied before in $V$. cholerae strains, but no clear correlation with specific virulence factors was found [2, 41], although biofilm formation in non-O1, non-O139 seems to be higher than in toxigenic strains.

\section{Conclusion}

This study was carried out to characterize virulence-related phenotypic and genotypic traits of Vibrio cholerae non-O1, non-O139 clinical strains isolated in central Europe in comparison to classical $\mathrm{O} 1$ and $\mathrm{O} 139$ toxigenic strains. While cases of diarrhea were mostly travel associated, ear and wound infections caused by $V$. cholerae strains may occur after direct contact to sea or lake waters in Europe. Interestingly, the study revealed that virulence factors like the type III secretion system (TTSS) and the multifunctional autoprocessing repeats-in-toxin (MARTX) toxin are not present in the latter strains, which indicates that these factors may be relevant only for intestinal infections. Non-O1, non-O139 strains are frequently found nowadays in the aquatic environment of central Europe and may increase in the future due to global warming. Because of the growing relevance to human health, fast diagnostic tools are required in order to discern environmental strains from potentially pathogenic strains. In further studies, we will analyze the prevalence of the potential marker genes analyzed in this study in environmental strains from German coastal waters collected in recent years to find out if they are of diagnostic value in this respect. Another source of possible Vibrio infections in Germany is seafood. While seafood consumption is increasing in Germany, most fish and fishery products are imported (http://faostat.fao.org/site/345/default.aspx). V. cholerae nonO1, non-O139 strains isolated from seafood are, so far, only 
tested for the $c t x$ gene and the serogroups $\mathrm{O} 1$ and $\mathrm{O} 139$. Additional testing for genes encoding TTSS and MARTX should be considered.

Acknowledgments We thank Drs. Susanne Dupke and Roland Grunow (RKI), Dr. Steliana Huhulescu (AGES), and Drs. Gerhard Hauk and Oliver Duty (LAGuS) for providing the strains. The International Centre for Diarrhoeal Disease Research, Bangladesh, is supported by countries and agencies which share its concern for the health problems of developing countries.

This work was supported by the Federal Ministry of Education and Research (VibrioNet, BMBF grant 01KI1015A).

Conflict of interest The authors declare that they have no conflict of interest.

Open Access This article is distributed under the terms of the Creative Commons Attribution License which permits any use, distribution, and reproduction in any medium, provided the original author(s) and the source are credited.

\section{References}

1. Mutreja A, Kim DW, Thomson NR, Connor TR, Lee JH, Kariuki S, Croucher NJ, Choi SY, Harris SR, Lebens M, Niyogi SK, Kim EJ, Ramamurthy T, Chun J, Wood JLN, Clemens JD, Czerkinsky C, Nair GB, Holmgren J, Parkhill J, Dougan G (2011) Evidence for several waves of global transmission in the seventh cholera pandemic. Nature 477(7365):462-465

2. Chatterjee S, Ghosh K, Raychoudhuri A, Chowdhury G, Bhattacharya MK, Mukhopadhyay AK, Ramamurthy T, Bhattacharya SK, Klose KE, Nandy RK (2009) Incidence, virulence factors, and clonality among clinical strains of non-O1, non-O139 Vibrio cholerae isolates from hospitalized diarrheal patients in Kolkata, India. J Clin Microbiol 47(4):1087-1095

3. Pang B, Yan M, Cui Z, Ye X, Diao B, Ren Y, Gao S, Zhang L, Kan B (2007) Genetic diversity of toxigenic and nontoxigenic Vibrio cholerae serogroups $\mathrm{O} 1$ and $\mathrm{O} 139$ revealed by array-based comparative genomic hybridization. J Bacteriol 189(13):4837-4849

4. Faruque SM, Chowdhury N, Kamruzzaman M, Dziejman M, Rahman MH, Sack DA, Nair GB, Mekalanos JJ (2004) Genetic diversity and virulence potential of environmental Vibrio cholerae population in a cholera-endemic area. Proc Natl Acad Sci U S A 101(7):2123-2128

5. Rivera ING, Chun J, Huq A, Sack RB, Colwell RR (2001) Genotypes associated with virulence in environmental isolates of Vibrio cholerae. Appl Environ Microbiol 67(6):2421-2429

6. Singh DV, Matte MH, Matte GR, Jiang S, Sabeena F, Shukla BN, Sanyal SC, Huq A, Colwell RR (2001) Molecular analysis of Vibrio cholerae O1, O139, non-O1, and non-O139 strains: clonal relationships between clinical and environmental isolates. Appl Environ Microbiol 67(2):910-921

7. Rahman MH, Biswas K, Hossain MA, Sack RB, Mekalanos JJ, Faruque SM (2008) Distribution of genes for virulence and ecological fitness among diverse Vibrio cholerae population in a cholera endemic area: tracking the evolution of pathogenic strains. DNA Cell Biol 27(7):347-355

8. Chow KH, Ng TK, Yuen KY, Yam WC (2001) Detection of RTX toxin gene in Vibrio cholerae by PCR. J Clin Microbiol 39(7):2594-2597

9. Satchell KJ (2007) MARTX, multifunctional autoprocessing repeatsin-toxin toxins. Infect Immun 75(11):5079-5084
10. Mathur J, Davis BM, Waldor MK (2007) Antimicrobial peptides activate the Vibrio cholerae sigmaE regulon through an OmpUdependent signalling pathway. Mol Microbiol 63(3):848-858

11. Mathur J, Waldor MK (2004) The Vibrio cholerae ToxR-regulated porin OmpU confers resistance to antimicrobial peptides. Infect Immun 72(6):3577-3583

12. Böer SI, Heinemeyer EA, Luden K, Erler R, Gerdts G, Janssen F, Brennholt N (2013) Temporal and spatial distribution patterns of potentially pathogenic Vibrio spp. at recreational beaches of the German north sea. Microb Ecol 65(4):1052-1067

13. Hauk G, Duty O, Littmann M (2010) Vibrio vulnificus in der Ostsee-klinische "Ausgangsfälle", Messstellen und Messdaten. Pathogene Vibrionen in der marinen Umwelt 3:23-30

14. Anonymous (2006) Nachweis von Vibrio cholerae non-O1, nonO139 bei einer immunsupprimierten Patientin nach Baden in Binnengewässern. Epidemiologisches Bull 34(295)

15. Huhulescu S, Indra A, Feierl G, Stoeger A, Ruppitsch W, Sarkar B, Allerberger F (2007) Occurrence of Vibrio cholerae serogroups other than $\mathrm{O} 1$ and $\mathrm{O} 139$ in Austria. Wien Klin Wochenschr 119(7-8):235-241

16. Baker-Austin C, Trinanes JA, Taylor NGH, Hartnell R, Siitonen A, Martinez-Urtaza J (2012) Emerging Vibrio risk at high latitudes in response to ocean warming. Nat Clim Change 3(1):73-77

17. Breidenbach J, Frank C (2012) Informationsbroschüre zu NichtCholera-Vibrionen in Deutschland. Robert Koch-Institut

18. Frank C, Littman M, Alpers K, Hallauer J (2006) Vibrio vulnificus wound infections after contact with the Baltic Sea, Germany. Euro Surveill 11:3024-3025

19. Bauer A, Rørvik LM (2007) A novel multiplex PCR for the identification of Vibrio parahaemolyticus, Vibrio cholerae and Vibrio vulnificus. Lett Appl Microbiol 45(4):371-375

20. Tarr CL, Patel JS, Puhr ND, Sowers EG, Bopp CA, Strockbine NA (2007) Identification of Vibrio isolates by a multiplex PCR assay and rpoB sequence determination. J Clin Microbiol 45(1):134-140

21. Dieckmann R, Strauch E, Alter T (2010) Rapid identification and characterization of Vibrio species using whole-cell MALDI-TOF mass spectrometry. J Appl Microbiol 109(1):199-211

22. Bier N, Bechlars S, Diescher S, Klein F, Hauk G, Duty O, Strauch E, Dieckmann R (2013) Genotypic diversity and virulence characteristics of clinical and environmental Vibrio vulnificus isolates from the baltic sea region. Appl Environ Microbiol 79(12):3570-3581

23. Moll A, Cabello F, Timmis KN (1979) Rapid assay for the determination of bacterial resistance to the lethal activity of serum. FEMS Microbiol Lett 6(5):273-276

24. Mahoney JC, Gerding MJ, Jones SH, Whistler CA (2010) Comparison of the pathogenic potentials of environmental and clinical Vibrio parahaemolyticus strains indicates a role for temperature regulation in virulence. Appl Environ Microbiol 76(22): 7459-7465

25. Farmer JJ III, Janda JM, Birkhead K (2007) Vibrio. In: Murray PR, Baron EJ, Jorgensen JH, Pfaller MA, Yolken RH (eds) Manual of clinical microbiology, 8th edn. American Society For Microbiology (ASM) Press, Washington DC, pp 706-718

26. Hoshino K, Yamasaki S, Mukhopadhyay AK, Chakraborty S, Basu A, Bhattacharya SK, Nair GB, Shimada T, Takeda Y (1998) Development and evaluation of a multiplex PCR assay for rapid detection of toxigenic Vibrio cholerae $\mathrm{O} 1$ and O139. FEMS Immunol Med Microbiol 20(3):201-207

27. Waldor MK, Mekalanos JJ (1996) Lysogenic conversion by a filamentous phage encoding cholera toxin. Science 272(5270):1910 1914

28. Bhattacharya T, Chatterjee S, Maiti D, Bhadra RK, Takeda Y, Nair GB, Nandy RK (2006) Molecular analysis of the rstR and orfU genes of the CTX prophages integrated in the small chromosomes of environmental Vibrio cholerae non-O1, non-O139 strains. Environ Microbiol 8(3):526-634 
29. Marsh JW, Taylor RK (1999) Genetic and transcriptional analyses of the Vibrio cholerae mannose-sensitive hemagglutinin type 4 pilus gene locus. J Bacteriol 181(4):1110-1117

30. Fallarino A, Attridge SR, Manning PA, Focareta T (2002) Cloning and characterization of a novel haemolysin in Vibrio cholerae $\mathrm{O} 1$ that does not directly contribute to the virulence of the organism. Microbiology 148(7):2181-2189

31. Dziejman M, Serruto D, Tam VC, Sturtevant D, Diraphat P, Faruque SM, Rahman MH, Heidelberg JF, Decker J, Li L, Montgomery KT, Grills G, Kucherlapati R, Mekalanos JJ (2005) Genomic characterization of non-O1, non-O139 Vibrio cholerae reveals genes for a type III secretion system. Proc Natl Acad Sci U S A 102(9):3465-3470

32. Purdy AE, Balch D, Lizárraga-Partida ML, Islam MS, MartinezUrtaza J, Huq A, Colwell RR, Bartlett DH (2010) Diversity and distribution of cholix toxin, a novel ADP-ribosylating factor from Vibrio cholerae. Environ Microbiol Rep 2(1):198-207

33. Awasthi SP, Asakura M, Chowdhury N, Neogi SB, Hinenoya A, Golbar HM, Yamate J, Arakawa E, Tada T, Ramamurthy T, Yamasaki S (2013) Novel cholix toxin variants, adp-ribosylating toxins in vibrio cholerae non-O1/non-O139 strains, and their pathogenicity. Infect Immun 81(2):531-541

34. Cheong TG, Chan M, Kurunathan S, Ali SA, ZiNing T, Zainuddin ZF, Lalitha P, Ravichandran M (2010) Construction and characterization of rtxA and rtxC mutants of auxotrophic O139 Vibrio cholerae. Microb Pathog 48(2):85-90

35. Hsieh SY, Tseng CL, Lee YS, Kuo AJ, Sun CF, Lin YH, Chen JK (2008) Highly efficient classification and identification of human pathogenic bacteria by MALDI-TOF MS. Mol Cell Proteomics 7(2):448-456

36. Seng P, Drancourt M, Gouriet F, La Scola B, Fournier PE, Rolain JM, Raoult D (2009) Ongoing revolution in bacteriology: routine identification of bacteria by matrix-assisted laser desorption ionization time-of-flight mass spectrometry. Clin Infect Dis 49(4):543-551
37. Dieckmann R, Helmuth R, Erhard M, Malorny B (2008) Rapid classification and identification of salmonellae at the species and subspecies levels by whole-cell matrix-assisted laser desorption ionization-time of flight mass spectrometry. Appl Environ Microbiol 74(24):7767-7778

38. Karger A, Ziller M, Bettin B, Mintel B, Schares S, Geue L (2011) Determination of serotypes of Shiga toxin-producing Escherichia coli isolates by intact cell matrix-assisted laser desorption ionization-time of flight mass spectrometry. Appl Environ Microbiol 77(3):896-905

39. Clark CG, Kruczkiewicz P, Guan C, McCorrister SJ, Chong P, Wylie J, van Caeseele P, Tabor HA, Snarr P, Gilmour MW, Taboada EN, Westmacott GR (2013) Evaluation of MALDI-TOF mass spectroscopy methods for determination of Escherichia coli pathotypes. J Microbiol Methods 94(3):180-191

40. Roig FJ, Sanjuán E, Llorens A, Amaro C (2010) pilF polymorphismbased PCR to distinguish Vibrio vulnificus strains potentially dangerous to public health. Appl Environ Microbiol 76(5):1328-1333

41. Fong JCN, Syed KA, Klose KE, Yildiz FH (2010) Role of Vibrio polysaccharide (vps) genes in VPS production, biofilm formation and Vibrio cholerae pathogenesis. Microbiology 156(Pt 9):2757-2769

42. Beutin L, Bode L, Richter T, Peltre G, Stephan R (1984) Rapid visual detection of Escherichia coli and Vibrio cholerae heat-labile enterotoxins by nitrocellulose enzyme-linked immunosorbent assay. J Clin Microbiol 19(3):371-375

43. Mantri CK, Mohapatra SS, Ramamurthy T, Ghosh R, Colwell RR, Singh DV (2006) Septaplex PCR assay for rapid identification of Vibrio cholerae including detection of virulence and int SXT genes. FEMS Microbiol Lett 265(2):208-214

44. Shuan Ju Teh C, Lin Thong K, Tein Ngoi S, Ahmad N, Balakrish Nair G, Ramamurthy T (2009) Molecular characterization of serogrouping and virulence genes of Malaysian Vibrio cholerae isolated from different sources. J Gen Appl Microbiol 55(6):419-425 